\title{
Effect of Drip Fertigation on the Plant Morphology and Crop Duration of Banana (cv. Martaman) in an Alluvial Soil
}

\author{
T. Basanta Singh ${ }^{1 *}$, S.K. Patra ${ }^{1}$, Chongtham Tania ${ }^{1}$, CH. Basudha Devi ${ }^{2}$ and \\ Thokchom Narjit Singh ${ }^{2}$
}

${ }^{1}$ Bidhan Chandra Krishi Viswavidyalaya, Mohanpur-741252, West Bengal, India

${ }^{2}$ ICAR Research Complex for NEH Region, Manipur Centre, Lamphelpat - 795004, Imphal, India

*Corresponding author

\begin{abstract}
A B S T R A C T
The field experiment was conducted at the Bidhan Chandra Krishi Viswavidyalaya, West Bengal to study the effect of drip fertigation on the plant morphology and crop duration of

Keywords

Drip fertigation, Banana, Morphological parameters, Crop duration, Alluvial soil

Article Info

Accepted: 26 October 2018 Available Online: 10 November 2018 banana (cv. Martaman-AAB group) in an alluvial soil during 2012 and 2013. The drip fertigation was done at four evapotranspiration (ET) based irrigation levels $\left(\mathrm{D}_{1}=0.6 \mathrm{ET}\right.$, $\mathrm{D}_{2}=0.8 \mathrm{ET}, \mathrm{D}_{3}=1.0 \mathrm{ET}$ for drip and surface irrigation $(\mathrm{S})$ at IW/CPE 1.0 and at three fertilizer levels of recommended doses of fertilizer (RDF) viz., $F_{1}=60 \%$ RDF, $F_{2}=80 \%$ $\mathrm{RDF}$ and $\mathrm{F}_{3}=100 \%$ RDF laid out in factorial randomized block design with three replications. In juvenile, vegetative and shooting stages the treatment, $\mathrm{D}_{3} \mathrm{~F}_{3}$ registered maximum pseudostem height $(100.3,204.6$ and $308.8 \mathrm{~cm})$, pseudostem girth $(36.1,66.3$ and $81.7 \mathrm{~cm})$, leaf breadth $(44.5,56.5$ and $62.3 \mathrm{~cm})$, leaf area $(107.5,153.6$ and $189.2 \mathrm{~cm})$, LAI $(0.97,2.13$ and 3.53$)$ and number of leaves $\left(8.5,11.8\right.$ and 13.3). The $\mathrm{D}_{3}$ level of drip irrigation shortened 18.0, 10.9 and 28.9 days to shooting, bunch harvest and total crop duration, respectively as compared with surface irrigation. The crop duration was shortest for combination $\mathrm{D}_{3} \mathrm{~F}_{3}$ as compared with other treatment combinations, whether drip or surface irrigation.
\end{abstract}

\section{Introduction}

Banana is one of the most important fruit crop in India. It is a typical fruit crop with higher demand for water and nutrients than common crops (Pan et al., 2011). In India, drip irrigation and fertigation is extensively used in the banana cultivation but the farmers generally follow conventional surface method of irrigation which is quite inefficient and non-remunerative. In banana cultivation, the major investment is incurred while hiring labour for irrigation (More et al., 2005). So, there is necessity to encourage farmers to adopt the drip irrigation method which could save about 40-70 percent of water for different crops and increase the crop productivity by 10-55 percent (Sharma and Kumar, 2007). Drip fertigation supplies water and plant nutrients in a regular and split manner. Timely supply of nutrients in a steady manner may lead to the early establishment with full 
vegetative growth before the reproductive stage. For any fruit pant, proper vegetative development is the determining factor for how fruitful will be the reproductive stage. If we could decrease the crop duration by drip fertigation or other method of irrigation or fertilization, farmers will be benefited in conserving time, space, inputs. Moreover, early marketable produce will fetch higher price and it will increase the economy of farmers. With the above aspects, it will be meaningful to study the effect of drip fertigation on the morphological characters and duration of banana crop.

\section{Materials and Methods}

The field experiment was conducted during the year 2012 and 2013 at the Central Research Farm, Gayeshpur, Bidhan Chandra Krishi Viswavidyalaya West Bengal encompassing the New Alluvial Zone $(9.75 \mathrm{~m}$ above MSL and $23^{\circ} \mathrm{N}$ and $89^{\circ} \mathrm{E}$ coordinate). The $\mathrm{pH}, \mathrm{EC}$, organic carbon percent, $\mathrm{N}, \mathrm{P}$ and $\mathrm{K}$ soil of the research field were respectively, $6.9,0.1 \mathrm{dS} / \mathrm{m}, 4.6,196.7 \mathrm{~kg} / \mathrm{ha}, 18.9 \mathrm{~kg} / \mathrm{ha}$ and $135.6 \mathrm{~kg} / \mathrm{ha}$. The groundwater having $\mathrm{pH}$ of 7.6 and EC of $0.62 \mathrm{dS} / \mathrm{m}$ was used to mix with fertilizer for irrigation. Healthy sword suckers (2-3 leaf) weighing around $1.5-2 \mathrm{~kg}$ each (2.02.5 month old) of banana cv. Martaman (AAB group) were planted (spacing $=2 \mathrm{~m} \times 2 \mathrm{~m}$ ) in the square pattern. The ratoon was maintained by retaining only one sucker per plant.

\section{Estimation of irrigation water requirement}

The reference crop evapotranspiration (ETo) was taken as the basis to calculate of crop water requirement (Doorenbos and Pruitt, 1977). Drip irrigation was provided to replenish 100, 80 and $60 \%$ of the ETo which is multiplied by suitable crop co-efficient $(\mathrm{Kc})$ values according to the crop stage, their product yields crop evapotranspiration (ETc). ETo was calculated by multiplying of pan evaporation (Ep) and pan factor $(\mathrm{Kp}=0.8)$. The daily Ep was recorded from the USWB classA pan installed inside the research farm. The monthly value of $\mathrm{Kc}$ for banana varied from 0.55 to 1.1 during first year and 1.0 to 1.2 during second year for three crop stages (Allen et al., 1998). The volume of water required per plot was computed based on the equation given by Vermeiren and Jobling (1980). The drip fertigation was done at four evapotranspiration (ET) based irrigation levels $\left(\mathrm{D}_{1}=0.6 \mathrm{ET}, \mathrm{D}_{2}=0.8 \mathrm{ET}, \mathrm{D}_{3}=1.0 \mathrm{ET}\right.$ for drip and surface irrigation (S) at IW/CPE 1.0) and at three fertilizer levels of recommended doses of fertilizer (RDF) viz., $\mathrm{F}_{1}=60 \%$ RDF, $\mathrm{F}_{2}=80 \% \mathrm{RDF}$ and $\mathrm{F}_{3}=100 \% \mathrm{RDF}$ laid out in factorial randomized block design with three replications. In case of surface irrigation, water was applied at IW/CPE 1.0 which is scheduled at 15-20 days' interval).

\section{Fertilizer source and scheduling}

Water soluble and cheaply available conventional fertilizers were used for the fertigation. Nitrogen was supplied through urea $(46 \% \mathrm{~N})$ as its primary source. Diammonium phosphate $\left(46 \% \mathrm{P}_{2} \mathrm{O}_{5}\right.$ and $\left.18 \% \mathrm{~N}\right)$ was used to supply phosphorus and also as secondary source of $\mathrm{N}$ and muriate of potash $\left(60 \% \mathrm{~K}_{2} \mathrm{O}\right)$ as the $\mathrm{K}$ source. These fertilizers are quite soluble in water, compatible to mixing together and convenient for drip fertigation (Kafkafi and Kant, 2005). The DAP fertilizer was dissolved in water one day before the irrigation with intermittent stirring and the suspensions were removed by filtering. The drip fertigation were scheduled in splits by targeting the active growth stages of banana. The fertigation was commenced nine weeks after planting. The nitrogen fertilizer was applied in 20 splits, phosphorus in two splits and potassium in nine splits. In conventional soil application of fertilizers followed by surface irrigation at IW/CPE 1.0, the whole amount of phosphorus and 50 
percent of nitrogen and potassium were broadcasted uniformly after seven weeks of planting around $30 \mathrm{~cm}$ to $70 \mathrm{~cm}$ distance from the plant base. The remaining nitrogen $(50 \%)$ was applied in 3 equal splits at 5, 7 and 9 months after planting and remaining potassium (50\%) was applied at 9 months after planting. The remaining fertilizers schedules for 80 percent and 60 percent of RDF were calculated accordingly.

\section{Plant biometric parameters}

The collection of data for plant morphological parameters were recorded at juvenile, critical growth and shooting stages The height of pseudostem $(\mathrm{cm})$ was measured from ground level to the uppermost point of contact of petioles of the two youngest leaves at juvenile (4 months), critical growth stage (7 months) and shooting (9-10 months) stages. The girth of pseudostem (cm) was measured $15 \mathrm{~cm}$ above the ground level at juvenile, vegetative and shooting stages. The length and breadth of leaf i.e., the distance from the axil to the distal tip and width at the broadest part, respectively was measured after margin of blade base was freed from contact with the petiole of the preceding leaf unit. Leaf area index is defined as the leaf area produced by plant per unit land area. LAI was computed at three growth stages of banana by using Digital Plant Canopy Imager (CI-110). It is the nondestructive method which captures canopy image and calculates LAI. The numbers of functional leaves were counted at juvenile, vegetative and shooting stages. The number of days was counted in days from date of planting to the date of shooting. The total number of days was counted from date of planting to date of bunch harvest.

\section{Statistical analysis}

To compare the effect of irrigation and fertilizer levels on morphological characters and crop duration, data were statistically analyzed following Gomez and Gomez (1984). The statistical differences of the data generated for each year and their pooled values were tested with least significant difference (LSD) at 5\% probability level using analysis of variance technique (ANOVA). The standard error of means $(\mathrm{SEm} \pm)$ and critical difference (CD) at 5\% level of significance were calculated to compare the treatment means. To observe the significance of differences between irrigation and fertilizer, the pairs of interaction mean values (first and second year) were compared by the Duncan's Multiple Range Test (DMRT) at probability $<0.05$ using SPSS software (Version 16.0). The means for groups in homogeneous sets are displayed with similar letters.

\section{Results and Discussion}

\section{Morphological characters}

The plant height at juvenile, critical growth and shooting stages of the crop were found to be significantly influenced by the increasing levels of drip irrigation and fertilizer. On an average, maximum pseudostem height of plant during juvenile, critical and shooting stages were observed to be $86.6,194.6$ and $297.9 \mathrm{~cm}$, respectively with the application of drip irrigation scheduled at 1.0 ETo $\left(\mathrm{D}_{3}\right)$, which was superior over other irrigation levels (Table 1). The corresponding values for plant height under surface irrigation were 78.3, 182.4 and $284.3 \mathrm{~cm}$, respectively which were markedly inferior at all stages as compared with other drip irrigation levels. Similarly, application of fertilizer at $100 \%$ of recommended dose of NPK $\left(\mathrm{F}_{3}\right)$ produced, on an average, the maximum pseudostem height of 93.2, 198.9 and $302.1 \mathrm{~cm}$ during juvenile, critical growth and shooting stages, respectively which is in line with the findings of Hegde and Srinivas (1990). The combination of drip irrigation at $100 \%$ of 
evaporation replenishment with fertigation at $100 \%$ of recommended NPK dose $\left(\mathrm{D}_{3} \mathrm{~F}_{3}\right)$ registered significantly highest pseudostem height of $100.3,204.6$ and $308.8 \mathrm{~cm}$ at juvenile, critical growth and shooting stages, respectively. On the other hand, the lowest pseudostem height was noticed under treatment $\mathrm{SF}_{1}$ which was comparable with $\mathrm{D}_{1} \mathrm{~F}_{1}$. Similar increase in pseudostem height in banana due to fertigation has been reported earlier by Pandey et al., (2001), Srinivas et al., (2001) and Kumar and Pandey (2008). The steady increase in pseudostem height through fertigation could be best explained with the regular supply of plant nutrients and water which increased the availability of $\mathrm{N}, \mathrm{P}$ and $\mathrm{K}$ in crop root zone ultimately leading to the enhanced uptake of these nutrients.

The pseudostem girth of plant, on an average, at juvenile, critical growth and shooting stages was 31.1, 61.0 and $77.0 \mathrm{~cm}$, respectively under drip irrigation scheduled at 1.0 ETo $\left(D_{3}\right)$, which was found to be superior to the remaining irrigation levels except at juvenile stage. The respective figures of pseudostem girth of plant under surface irrigation were 26.5, 51.2 and $69.8 \mathrm{~cm}$, respectively. The reduced pseudostem girth in ratoon crop than in plant crop as observed in the present study is in agreement with the reports of Hegde and Srinivas (1990).

Irrespective of irrigation levels, application of fertilizers at $100 \%$ of RDF of NPK $\left(\mathrm{F}_{3}\right)$, on an average, recorded the maximum pseudostem girth of 33.3, 61.1 and $78.2 \mathrm{~cm}$ at juvenile, critical growth and shooting stages, respectively in plant and ratoon crop. The thicker pseudostem girth in plant crop than the ratoon crop might be due to the additive effect of pre-planting application of FYM (10 kg/pit) coupled with the native soil nutrients uniformly other than the externally supplied NPK fertilizers. Hegde and Srinivas (1990) also found thinner pseudostem girth in the ratoon crop. Low $\mathrm{N}$ fertilizer application reduced pseudostem growth (Dorel et al., 2008).

The interaction between the levels of irrigation and fertilizers on pseudostem girth of plant was significantly affected at the three crop stages in both seasons with some exceptions. Drip irrigation at $100 \%$ of ETo with fertigation at $100 \%$ RDF of NPK, $\left(\mathrm{D}_{3} \mathrm{~F}_{3}\right)$ recorded significantly the highest pseudostem girth of $36.1,66.3$ and $81.7 \mathrm{~cm}$ at juvenile, critical growth and shooting stages, respectively. On the other hand, the lowest pseudostem girth of plant was observed under surface irrigation with conventional soil fertilization $\left(\mathrm{SF}_{1}\right)$ in plant and ratoon crop at all the stages.

The fertigation through drip system as a whole significantly increased pseudostem girth compared to the surface method of irrigation and soil fertilization. The steady increase in pseudostem girth through drip fertigation could be due to the timely supply of requisite plant nutrients and water which resulted in ready availability of $\mathrm{N}, \mathrm{P}$ and $\mathrm{K}$ nutrients in crop root zone ultimately leading to the enhanced uptake of these nutrients. Similar increase in pseudostem girth in banana due to fertigation has been reported earlier (Mahalakshmi et al., 2001; Srinivas et al., 2001; Kumar and Pandey, 2008).

\section{Leaf breadth, length and LAI}

The leaf breadth at three growth stages i.e., juvenile, critical growth and shooting stage under drip irrigation at $100 \%$ of ETo $\left(D_{3}\right)$ were $40.8,51.5$ and $58 \mathrm{~cm}$, respectively, while the corresponding values for conventional surface irrigation were $34.6,46.1$ and $54.3 \mathrm{~cm}$, respectively. This implied that drip irrigation at higher levels had marked effect in promoting the leaf breadth over surface irrigation. 
Table.1 Effect of different irrigation and fertilizer treatments on morphological characters of banana

\begin{tabular}{|c|c|c|c|c|c|c|c|c|c|c|c|c|c|c|c|}
\hline \multirow{2}{*}{$\begin{array}{l}\text { Treatments } \\
\text { Irrigation } \\
\text { (I) }\end{array}$} & \multicolumn{3}{|c|}{ Pseudostem height } & \multicolumn{3}{|c|}{ Pseudostem girth $(\mathrm{cm})$} & \multicolumn{3}{|c|}{ Leaf breadth (g) } & \multicolumn{3}{|c|}{ LAI } & \multicolumn{3}{|c|}{ Leaf length } \\
\hline & $\begin{array}{l}\text { Juvenile } \\
\text { stage }\end{array}$ & $\begin{array}{l}\text { Critical } \\
\text { growth } \\
\text { phase }\end{array}$ & $\begin{array}{l}\text { Shooting } \\
\text { stage }\end{array}$ & $\begin{array}{l}\text { Juvenile } \\
\text { stage }\end{array}$ & $\begin{array}{l}\text { Critical } \\
\text { growth } \\
\text { phase }\end{array}$ & $\begin{array}{l}\text { Shooting } \\
\text { stage }\end{array}$ & $\begin{array}{l}\text { Juvenile } \\
\text { stage }\end{array}$ & $\begin{array}{l}\text { Critical } \\
\text { growth } \\
\text { phase }\end{array}$ & $\begin{array}{l}\text { Shooting } \\
\text { stage }\end{array}$ & $\begin{array}{l}\text { Juvenile } \\
\text { stage }\end{array}$ & $\begin{array}{l}\text { Critical } \\
\text { growth } \\
\text { phase }\end{array}$ & $\begin{array}{l}\text { Shooting } \\
\text { stage }\end{array}$ & $\begin{array}{l}\text { Juvenile } \\
\text { stage }\end{array}$ & $\begin{array}{l}\text { Critical } \\
\text { growth } \\
\text { phase }\end{array}$ & $\begin{array}{l}\text { Shooting } \\
\text { stage }\end{array}$ \\
\hline$\overline{D_{1}}$ & 78.4 & 184.8 & 287.9 & 28.4 & 55.2 & 73.8 & 36.3 & 46.9 & 55.2 & 0.49 & 1.44 & 2.52 & 88.8 & 136.9 & 177.1 \\
\hline $\mathrm{D}_{2}$ & 81.7 & 191.6 & 294.3 & 31.2 & 58.1 & 75.6 & 39.9 & 50.3 & 57.5 & 0.61 & 1.64 & 2.75 & 97.7 & 144.7 & 181.4 \\
\hline $\mathrm{D}_{3}$ & 86.6 & 194.6 & 297.9 & 31.1 & 61.0 & 77.0 & 40.8 & 51.5 & 58.0 & 0.66 & 1.75 & 2.89 & 98.8 & 146.2 & 182.4 \\
\hline $\mathbf{S}$ & 78.3 & 182.4 & 284.3 & 26.5 & 51.2 & 69.8 & 34.6 & 46.1 & 54.3 & 0.48 & 1.44 & 2.56 & 81.5 & 127.7 & 163.0 \\
\hline $\operatorname{SEm}( \pm)$ & 0.360 & 0.464 & 0.422 & 0.384 & 0.470 & 0.320 & 0.224 & 0.376 & 0.387 & 0.006 & 0.010 & 0.014 & 0.249 & 0.253 & 0.268 \\
\hline CD (0.05) & 1.025 & 1.321 & 1.203 & 1.094 & 1.340 & 0.912 & 0.639 & 1.072 & 1.104 & 0.017 & 0.028 & 0.041 & 0.709 & 0.722 & 0.764 \\
\hline \multicolumn{16}{|l|}{ Fertilize $(F)$} \\
\hline$F_{1}$ & 70.8 & 178.3 & 280.1 & 25.7 & 51.8 & 69.8 & 32.7 & 44.1 & 52.1 & 0.35 & 1.19 & 2.22 & 80.0 & 128.6 & 167.9 \\
\hline$F_{2}$ & 79.8 & 187.9 & 291.2 & 28.9 & 56.3 & 74.2 & 38.8 & 49.5 & 56.3 & 0.57 & 1.60 & 2.72 & 93.0 & 140.6 & 177.3 \\
\hline$F_{3}$ & 93.2 & 198.9 & 302.1 & 33.3 & 61.1 & 78.2 & 42.2 & 52.4 & 60.4 & 0.76 & 1.91 & 3.10 & 102.1 & 147.5 & 182.7 \\
\hline $\operatorname{SEm}( \pm)$ & 0.312 & 0.401 & 0.365 & 0.332 & 0.407 & 0.277 & 0.194 & 0.326 & 0.335 & 0.005 & 0.008 & 0.012 & 0.215 & 0.220 & 0.232 \\
\hline CD $(0.05)$ & 0.888 & 1.144 & 1.042 & 0.948 & 1.160 & 0.790 & 0.554 & 0.929 & 0.956 & 0.015 & 0.024 & 0.035 & 0.614 & 0.626 & 0.661 \\
\hline \multicolumn{16}{|c|}{ Irrigation $x$ Fertilizer } \\
\hline $\mathrm{D}_{1} \mathrm{~F}_{1}$ & $68.2^{\mathrm{a}}$ & $170.8^{\mathrm{a}}$ & $274.8^{\mathrm{abc}}$ & $25.4^{\mathrm{ab}}$ & $51.3^{\mathrm{abc}}$ & $68.8^{\mathrm{ab}}$ & $29.3^{\mathbf{a b}}$ & $41.4^{\mathrm{a}}$ & 51.3 & $0.26^{\mathrm{a}}$ & $1.06^{\mathrm{a}}$ & $2.09^{\mathrm{a}}$ & $71.9^{\mathbf{a b}}$ & $122.8^{\mathrm{a}}$ & $167.9^{b c}$ \\
\hline$D_{1} F_{2}$ & $77.9^{\text {abc }}$ & $185.5^{\mathrm{cd}}$ & $289.8^{\text {de }}$ & $27.6^{\text {abcd }}$ & $54.7^{\text {abcd }}$ & $73.8^{\text {bcdef }}$ & $38.0^{\text {cd }}$ & $48.5^{\mathrm{bc}}$ & 54.8 & $0.51^{\mathrm{cd}}$ & $1.43^{\mathrm{c}}$ & $2.54^{\mathrm{abcd}}$ & $92.8 \mathrm{~d}^{\mathrm{ef}}$ & $138.3^{b}$ & $178.8^{\text {efg }}$ \\
\hline$D_{1} F_{3}$ & $89.1^{\text {cde }}$ & $198.1^{\text {ef }}$ & $299.2^{\text {ef }}$ & $32.3^{\text {de }}$ & $59.5^{\text {cde }}$ & $78.7^{\mathrm{efg}}$ & $41.7^{\mathrm{efg}}$ & $50.8^{\text {cd }}$ & 59.4 & $0.69^{\mathrm{g}}$ & $1.82^{\mathrm{f}}$ & $2.94^{\text {cde }}$ & $101.8^{\mathrm{fg}}$ & $149.4^{\mathrm{c}}$ & $184.7^{\text {chh }}$ \\
\hline $\mathrm{D}_{2} \mathrm{~F}_{1}$ & $71.6^{\mathbf{a b}}$ & $183.9^{\text {bcd }}$ & $283.6^{\mathrm{bc}}$ & $26.7^{\mathbf{a b c}}$ & $53.6^{\text {abcd }}$ & $71.0^{\mathrm{abcd}}$ & $36.0^{\mathbf{b}}$ & $46.0^{\mathbf{b}}$ & 52.7 & $0.43^{\mathbf{b}}$ & $1.27^{\mathbf{b}}$ & $2.28^{\mathrm{ab}}$ & $88.0^{\text {cd }}$ & $133.4^{\mathrm{b}}$ & $172.4^{\mathrm{de}}$ \\
\hline $\mathrm{D}_{2} \mathrm{~F}_{2}$ & $78.9^{\text {abc }}$ & $190.0^{\text {cde }}$ & $295.3^{\text {def }}$ & $31.7^{\text {cde }}$ & $58.3^{\text {bcde }}$ & $75.8^{\text {cdefg }}$ & $40.8^{\text {def }}$ & $51.0^{\text {cd }}$ & 58.5 & $0.60^{\mathrm{ef}}$ & $1.71^{\mathrm{e}}$ & $2.83^{\text {bcde }}$ & $100.3^{\mathrm{fg}}$ & $148.6^{\mathrm{c}}$ & $184.5^{\text {gh }}$ \\
\hline $\mathrm{D}_{2} \mathrm{~F}_{3}$ & $94.5^{\mathrm{de}}$ & $201.0^{\mathrm{ef}}$ & $304.1^{\mathrm{fg}}$ & $35.2^{\mathrm{e}}$ & $62.5^{\mathrm{de}}$ & $79.8^{\mathrm{fg}}$ & $43.0^{\mathrm{fg}}$ & $54.0^{\mathrm{de}}$ & 61.3 & $0.78^{h}$ & $1.95^{\mathrm{g}}$ & $3.14^{\mathrm{de}}$ & $104.7^{\mathrm{g}}$ & $152.1^{\mathrm{c}}$ & $187.3^{\mathrm{h}}$ \\
\hline$D_{3} F_{1}$ & $75.4^{\text {ab }}$ & $185.2^{\text {cd }}$ & $288.4^{\text {cd }}$ & $27.5^{\text {abcd }}$ & $54.5^{\text {abcd }}$ & $72.3^{\text {abcd }}$ & $36.6^{\mathrm{bc}}$ & $47.2^{b}$ & 53.8 & $0.45^{\mathrm{bc}}$ & $1.40^{\mathrm{c}}$ & $2.39^{\mathrm{abc}}$ & $89.8^{\text {de }}$ & $136.6^{\mathbf{b}}$ & $175.7^{\mathrm{def}}$ \\
\hline$\overline{D_{3} F_{2}}$ & $84.2^{\text {bcd }}$ & $194.0^{\mathrm{def}}$ & $296.6^{\mathrm{def}}$ & $29.5^{\text {bcd }}$ & $62.2^{\mathrm{de}}$ & $77.0^{\text {defg }}$ & $41.4^{\mathrm{efg}}$ & $50.7^{\mathrm{cd}}$ & 58.0 & $0.64^{\mathrm{fg}}$ & $1.73^{\mathrm{e}}$ & $2.90^{\text {bcde }}$ & $99.0^{\mathrm{efg}}$ & $148.6^{c}$ & $182.3^{\mathrm{fgh}}$ \\
\hline$\overline{D_{3} F_{3}}$ & $100.3^{\mathrm{e}}$ & $204.6^{\mathrm{f}}$ & $308.8^{\mathrm{g}}$ & $36.1^{\mathrm{e}}$ & $66.3^{\mathrm{e}}$ & $81.7^{\mathrm{g}}$ & $44.5^{\mathrm{g}}$ & $56.5^{\mathrm{e}}$ & 62.3 & $0.90^{\mathrm{i}}$ & $2.13^{\mathrm{h}}$ & $3.37^{\mathrm{e}}$ & $107.5^{\mathrm{g}}$ & $153.6^{\mathrm{c}}$ & $189.2^{\mathrm{h}}$ \\
\hline $\mathrm{SF}_{1}$ & $68.0^{\mathrm{a}}$ & $173.3^{\text {ab }}$ & $273.5^{\mathrm{a}}$ & $23.1^{\mathrm{a}}$ & $47.7^{\mathbf{a}}$ & $66.8^{\mathrm{a}}$ & $29.1^{\mathrm{a}}$ & $41.8^{\mathrm{a}}$ & 50.5 & $0.25^{\mathrm{a}}$ & $1.04^{\mathrm{a}}$ & $2.12^{\mathrm{a}}$ & $70.2^{\mathrm{a}}$ & $121.4^{\mathrm{a}}$ & $155.6^{\mathrm{a}}$ \\
\hline $\mathrm{SF}_{2}$ & $78.3^{\text {abc }}$ & $182.2^{\mathrm{bc}}$ & $283.0^{\mathrm{abc}}$ & $26.8^{\mathrm{abc}}$ & $49.8^{\mathbf{a b}}$ & $70.0^{\mathrm{abc}}$ & $35.2^{\mathrm{b}}$ & $48.0^{\mathbf{b c}}$ & 53.7 & $0.53^{\mathrm{de}}$ & $1.53^{\mathrm{d}}$ & $2.60^{\text {abcd }}$ & $79.9^{\mathbf{b c}}$ & $127.0^{\mathrm{a}}$ & $163.6^{b}$ \\
\hline $\mathrm{SF}_{3}$ & $88.7^{\text {cde }}$ & $191.9^{\text {cde }}$ & $296.4^{\text {def }}$ & $29.5^{\text {abcd }}$ & $56.0^{\text {abcd }}$ & $72.7^{\text {abcde }}$ & $39.5^{\text {cde }}$ & $48.5^{\mathbf{b c}}$ & 58.8 & $0.66^{\mathrm{fg}}$ & $1.75^{\text {ef }}$ & $2.96^{\text {cde }}$ & $94.4^{\text {def }}$ & $134.7^{\mathbf{b}}$ & $169.8^{\text {bcd }}$ \\
\hline $\operatorname{SEm}( \pm)$ & 0.623 & 0.803 & 0.731 & 0.665 & 0.814 & 0.554 & 0.389 & 0.652 & 0.671 & 0.011 & 0.017 & 0.025 & 0.431 & 0.439 & 0.464 \\
\hline CD (0.05) & 1.776 & 2.289 & 2.083 & 1.895 & 2.321 & 1.580 & 1.107 & 1.857 & NS & 0.030 & 0.048 & 0.071 & 1.228 & 1.251 & 1.323 \\
\hline
\end{tabular}




\begin{tabular}{|c|c|c|c|c|c|c|c|c|c|}
\hline Treatments & \multicolumn{3}{|c|}{ Days to shooting } & \multicolumn{3}{|c|}{ Days to bunch harvest } & \multicolumn{3}{|c|}{ Total crop duration } \\
\hline Irrigation (I) & Crop I & Crop II & Pooled & Crop I & Crop II & Pooled & Crop I & Crop II & Pooled \\
\hline $\mathrm{D}_{1}$ & 324.3 & 295.7 & 310.0 & 94.7 & 91.3 & 93.0 & 419.0 & 387.0 & 403.0 \\
\hline$\overline{D_{2}}$ & 324.8 & 290.3 & 307.6 & 90.0 & 88.0 & 89.0 & 414.8 & 378.3 & 396.6 \\
\hline$\overline{D_{3}}$ & 324.1 & 280.3 & 302.2 & 93.7 & 86.3 & 90.0 & 417.8 & 366.7 & 392.2 \\
\hline S & 334.6 & 305.9 & 320.2 & 101.3 & 100.4 & 100.9 & 435.9 & 406.3 & 421.1 \\
\hline SEm $( \pm)$ & 1.12 & 1.11 & 0.79 & 0.62 & 0.82 & 0.52 & 1.44 & 1.42 & 1.01 \\
\hline CD (0.05) & 3.28 & 3.25 & 2.25 & 1.83 & 2.41 & 1.47 & 4.23 & 4.17 & 2.89 \\
\hline \multicolumn{10}{|l|}{ Fertilizer $(F)$} \\
\hline $\mathrm{F}_{1}$ & 332.8 & 300.3 & 316.6 & 94.9 & 95.3 & 95.1 & 427.8 & 395.6 & 411.7 \\
\hline$\overline{F_{2}}$ & 325.5 & 293.4 & 309.5 & 95.5 & 90.5 & 93.0 & 421.0 & 383.9 & 402.5 \\
\hline$F_{3}$ & 322.5 & 285.4 & 304.0 & 94.3 & 88.8 & 91.6 & 416.8 & 374.3 & 395.5 \\
\hline $\operatorname{SEm}( \pm)$ & 0.97 & 0.96 & 0.68 & 0.54 & 0.71 & 0.45 & 1.25 & 1.23 & 0.88 \\
\hline CD (0.05) & 2.84 & 2.82 & 1.94 & NS & 2.09 & 1.27 & 3.67 & 3.61 & 2.50 \\
\hline \multicolumn{10}{|c|}{ Irrigation $x$ Fertilizer } \\
\hline $\mathrm{D}_{1} \mathrm{~F}_{1}$ & 326.0 & 303.3 & $314.7^{\mathbf{a}}$ & 98.3 & 94.0 & $96.2^{\mathbf{a b}}$ & 424.3 & 397.3 & 410.8 \\
\hline $\mathrm{D}_{1} \mathrm{~F}_{2}$ & 325.3 & 296.3 & $310.8^{\mathrm{a}}$ & 95.3 & 90.7 & $93.0^{\mathbf{a b}}$ & 420.7 & 387.0 & 403.8 \\
\hline$D_{1} F_{3}$ & 321.7 & 287.3 & $304.5^{\mathrm{a}}$ & 90.3 & 89.3 & $89.8^{\mathbf{a}}$ & 412.0 & 376.7 & 394.3 \\
\hline $\mathrm{D}_{2} \mathrm{~F}_{1}$ & 337.3 & 296.7 & $317.0^{a}$ & 83.0 & 94.3 & $88.7^{\mathrm{a}}$ & 420.3 & 391.0 & 405.7 \\
\hline$D_{2} F_{2}$ & 320.7 & 291.7 & $306.2^{\mathrm{a}}$ & 91.3 & 86.3 & $88.8^{\mathrm{a}}$ & 412.0 & 378.0 & 395.0 \\
\hline$D_{2} F_{3}$ & 316.3 & 282.7 & $299.5^{a}$ & 95.7 & 83.3 & $89.5^{\mathrm{a}}$ & 412.0 & 366.0 & 389.0 \\
\hline $\mathrm{D}_{3} \mathrm{~F}_{1}$ & 331.7 & 289.0 & $310.3^{a}$ & 94.0 & 88.3 & $91.2^{\mathrm{a}}$ & 425.7 & 377.3 & 401.5 \\
\hline $\mathrm{D}_{3} \mathrm{~F}_{2}$ & 322.0 & 280.0 & $301.0^{\mathbf{a}}$ & 93.0 & 87.3 & $90.2^{\mathrm{a}}$ & 415.0 & 367.3 & 391.2 \\
\hline$D_{3} F_{3}$ & 318.7 & 272.0 & $295.3^{\mathrm{a}}$ & 94.0 & 83.3 & $88.7^{\mathrm{a}}$ & 412.7 & 355.3 & 384.0 \\
\hline $\mathrm{SF}_{1}$ & 336.3 & 312.3 & $324.3^{\mathrm{a}}$ & 104.3 & 104.3 & $104.3^{b}$ & 440.7 & 416.7 & 428.7 \\
\hline $\mathrm{SF}_{2}$ & 334.0 & 305.7 & $319.8^{\mathbf{a}}$ & 102.3 & 97.7 & $100.0^{\mathbf{a b}}$ & 436.3 & 403.3 & 419.8 \\
\hline $\mathrm{SF}_{3}$ & 333.3 & 299.7 & $316.5^{\mathbf{a}}$ & 97.3 & 99.3 & $98.3^{\mathbf{a b}}$ & 430.7 & 399.0 & 414.8 \\
\hline $\operatorname{SEm}( \pm)$ & 1.94 & 1.92 & 1.36 & 1.08 & 1.42 & 0.89 & 2.50 & 2.46 & 1.75 \\
\hline CD (0.05) & 5.68 & NS & 3.89 & 3.16 & NS & 2.55 & NS & NS & NS \\
\hline
\end{tabular}

Similarly, irrespective of irrigation levels, the increasing fertilizer doses progressively enhanced the leaf breadth significantly at all the stages of crops. Maximum leaf breadth was observed in $\mathrm{D}_{3} \mathrm{~F}_{3}$ in all cases, while the minimum values for the same were recorded in surface irrigation with soil fertilization $\left(\mathrm{SF}_{1}\right)$ and they were comparable with $\mathrm{D}_{1} \mathrm{~F}_{1}$. The non-significance of leaf breadth with higher fertilizer levels has been reported by Srinivas (1997). The leaf area index (LAI), leaf length of plant was significantly affected by the methods and levels of irrigation and increasing fertilizer application as that of plant height, pseudostem girth and leaf breadth. In general, drip fertigation resulted in relatively higher LAI in the three stages compared to conventional method of irrigation and soil fertilization. Increasing level of evaporation replenishment or fertilization regardless of irrigation methods and application results significantly higher LAI of both the crops. This increment might be due to increase in leaf area and number of leaves per plant under the influence of judicious amounts of irrigation water and nutrients available to plants (Hegde and Srinivas, 1991; Srinivas et al., 2001). The interaction between irrigation and fertilizer levels on LAI at different stages was significant. Treatment combination $\mathrm{D}_{3} \mathrm{~F}_{3}$ gave maximum LAI of $0.97,2.13$ and 3.53 at 
juvenile, critical growth and shooting stages, respectively. The lowest LAI was noticed under the treatment $\mathrm{D}_{1} \mathrm{~F}_{1}$ for drip and $\mathrm{SF}_{1}$ for surface irrigation.

\section{Time of shooting, bunch harvesting and crop duration}

The effect of irrigation and fertilizer levels on days to shooting, days to bunch harvest and crop duration at all the growth stages were found to be significant. In general, drip irrigation at varying level was quite effective in promoting relatively early crop by advancing harvesting period as compared with conventional surface irrigation (Table 2). Similarly, higher level of NPK application, irrespective of irrigation methods, also resulted in early cropping of both plants. Overall the drip irrigation at $100 \%$ of evaporation replenishment $\left(D_{3}\right)$ shortened the shooting by 18.0 days, bunch harvesting by 10.9 days and total crop duration by 28.9 days as compared with conventional surface irrigation. On the other hand, higher level of fertilization with $100 \%$ of recommended dose of NPK fertilizers $\left(\mathrm{F}_{3}\right)$ shortened the period, on an average, by 12.6 days to shooting, 3.5 days for bunch harvesting and 16.2 days to total crop duration as compared with lower level of fertilization with $60 \%$ of recommended dose of NPK fertilizers $\left(F_{1}\right)$. These results are in accordance with the findings of Figueiredo et al., (2006). The significant difference in days to shooting and bunch harvest with fertigation levels has also been reported by Hegde and Srinivas (1990) and Badgujar et al., (2004). This might be attributed to more time taken by the plant crop for establishment after planting contrary to the ratoon crop which enjoyed the wellestablished growing soil environment. The interactions between irrigation and fertilizer at varying levels also figured the same results as in main effects of irrigation and fertilizer levels. However, the treatment combination of
$\mathrm{D}_{3} \mathrm{~F}_{3}$ was found promising in attaining the advancement of these parameters as compared to other treatment combinations. Similar results have also been reported by Mahalakshmi et al., (2001). The decrease in the cropping period may be due to the regular supply of judicious amounts of water and NPK nutrients and consequent availability and uptake by plants, which ultimately led to the early physiological maturity of crops. It is conducive for conserving time, space, inputs and catching the early market. Shorter crop duration in banana by drip irrigation was reported by several workers (Hegde and Srinivas, 1991; Salvin et al., 2000; Pandey et al., 2001; Shashidhara et al., 2007; Teixeira et al., 2007; Kumar and Pandey, 2008).

The drip fertigation has positive effect on the morphological characters and crop duration attributes of banana. Early establishment of plant can lead to early flowering and fruiting which will ultimately benefit the farmers. It can be concluded that with increasing levels of irrigation and fertilizer levels, there is more vegetative growth and also shortens the crop duration. Therefore, it is explicit that farmers can increase income by adopting drip fertigation in banana farming by virtue of better growth.

\section{Acknowledgement}

The authors are thankful to Department of Soil Science and Agricultural Chemistry, Bidhan Chandra Krishi Viswavidyalaya, Mohanpur, West Bengal for providing the facility and technical support to carry out this field experiment.

\section{References}

Allen, R. G., Pereira, L. S., Raes, D., and Smith, M. 1998. Crop evapotranspiration-guidelines for computing crop water requirements. 
Irrigation and Drainage Paper No. 56. FAO, Rome, Italy, p 300.

Badgujar, C. D., Deshmukh, S. S., Dusane, S. M. and Shide, S. S. 2004. Influence of ' $\mathrm{N}$ ' and ' $\mathrm{K}$ ' fertigation and different plant densities on yield of Banana cv. Grand Naine. South Indian Horticulture 52, 22-28.

Doorenbos, J. and Pruitt, W. O. 1977. Crop water requirement. Irrigation and Drainage Paper No. 24, FAO, Rome.

Dorel, M., Achard, R., Tixier, P. and SIMBA, N 2008. Modeling nitrogen dynamics in banana populations in wet tropical climate. Application to fertilization management in the Caribbean. European Journal of Agronomy 29(1): $38-45$.

Figueiredo de, F.P., Mantovani, E.C, Soares, A.A., Costa, L.C, Ramos, M.M. and Oliveira, F.G. (2006) Productivity and quality of banana prata ana influenced by water depths, cultivated in the Northern Minas Gerais, Brazil. Revista Brasileira de Engenharia Agricola-eAmbiental 10(4), 798-803.

Gomez, K. A. \& Gomez, A. A. 1984. Statistical procedures for agricultural research, John Wiley and Sons, Ink., New York.

Kafkafi, U. and Kant, S. 2005. Fertigation. InEncyclopedia of soils in the environment (vol. II) (Ed. Daniel Hillel) Elsevier Ltd., pp. 1-9.

Kumar, D. and Pandey, V. 2008. Effect of NPK fertigation on growth, yield and quality of banana 'Rasthali' (AABPathkapoora) in coastal agro-climatic conditions of eastern India. Indian Journal of Agricultural Sciences 78(9): 798-800.

Mahalakshmi, M., Kumar, N., Jayakumar, P. and Soorianathasundaram, K. 2001. Fertigation studies in banana under high density planting system. InProceedings of a National Seminar on
Changing Scenario in the Production Systems of Horticultural Crops., Coimbatore, Tamil Nadu, India, 28-30 August 2001. South Indian Horticulture 49(Sp.): 86-91.

Pan, N., Shen, H., Wu, D.M., Deng, L.S., Tu, P.F., Gan, H.H. and Liang, Y.C. (2011) Mechanism of improved phosphate uptake efficiency in banana seedlings on acidic soils using fertigation. Agricultural Water Management 98, 632-638.

Pandey, S.D., Jeyabaskaran, K.J., Laxman, R.H., Santhi, V.P. and Mustaffa, M.M. (2001) Effect of irrigation, $\mathrm{N}$ fertigation and planting geometry on growth and yield of banana cv. Nendran. South Indian Horticulture 49, 76-79.

Salvin, S., Baruah, K. and Bordoloi, S.K. (2000) Drip irrigation studies in banana cv. Barjahaji (Musa AAA group, Cavendish sub-group). Crop Research 20, 489-493.

Shashidhara, K.K., Bheemappa, A., Hirevenkanagoudar, L.V. and Shashidhar, K.C. (2007) Benefits and constraints in adoption of drip irrigation among the plantation crop growers. Karnataka Journal of Agricultural Sciences 20, 82-84.

Srinivas, K. (1997) Growth, yield, and quality of banana in relation to $\mathrm{N}$ fertigation. Tropical Agriculture 1 (4), 260-264.

Srinivas, K., Reddy, B. M. C., Kumar, S. S. C, Gowda, S. T., Raghupati, H. B. and Padma, P. 2001. Growth, yield and nutrient uptake of Robusta banana in relation to $\mathrm{N}$ and $\mathrm{K}$ fertigation. Indian Journal of Horticulture 58 (4): 287-293.

Teixeira, L.A.J., Natale, W. and Martins, A.L.M. (2007) Nitrogen and potassium application on banana plant by fertirrigation and conventional fertilization -nutritional status of banana plants and fruit production. Revista 
Brasileira de Fruticultura 29 (1), 153160.

Vermeiren, I. and Jobling, G. A. 1980.

Localized irrigation design, installation, operation and evaluation. Irrigation and Drainage Paper No. 36, FAO, Rome, $10-12$.

\section{How to cite this article:}

Basanta Singh, T., S.K. Patra, Chongtham Tania, CH. Basudha Devi and Thokchom Narjit Singh. 2018. Effect of Drip Fertigation on the Plant Morphology and Crop Duration of Banana (cv. Martaman) in an Alluvial Soil. Int.J.Curr.Microbiol.App.Sci. 7(11): 3307-3315. doi: https://doi.org/10.20546/ijcmas.2018.711.382 